\title{
Market Orientation as The Appropriate Approach for SMEs In Dealing With External Environmental Factors
}

\author{
James Rianto Situmorang \\ Department of Business Administration, \\ Universitas Padjadjaran, Bandung, Indonesia \\ Sam'un Jaja Raharja \\ Department of Business Administration, \\ Universitas Padjadjaran, Bandung, Indonesia \\ Erna Maulina \\ Department of Business Administration, \\ Universitas Padjadjaran, Bandung, Indonesia \\ Anang Muftiadi \\ Department of Business Administration, \\ Universitas Padjadjaran, Bandung, Indonesia
}

\begin{abstract}
Since it first appeared in 1990, market orientation has been a research topic that is popular among academics until present time. Market orientation can be divided into two categories, cultural approach according to Narver \& Slater and behavioral approach according to Jaworski \& Kohli. Market orientation by Narver \& Slater is widely used by market orientation researchers at the SME level. UKM as a business unit cannot be separated from its external environmental factors. External environmental factors according to Kohli \& Jaworski are market turbulence, technological turbulence, and the competitive intensity. Some studies measure the effect of market orientation on company performance that includes external environmental factor variables. The results of the study generally indicate that market orientation and external environmental factors positively affect the company performance. Thus, market orientation is the appropriate approach for SMEs in dealing with external environmental factors
\end{abstract}

Keywords: Market orientation, external environment factor, customer orientation, competitor orintation, inter-functional coordination, market turbulence, technology turbulence, competitive intensity.

\section{INTRODUCTION}

Market orientation is a topic widely analyzed and debated in the current literature of marketing since 1990 decade. In 1990s, two approaches have dominated the conceptualization of market orientation. On the one hand, Narver and Slater (1990) proposed three key components: customer orientation, competitor orientation and interfunctional coordination. The three components were defined as follows: 1) customer orientation is the sufficient understanding of one's target buyers so as to be able to create superior value for them continuously; 2) competitor orientation is that a seller understandsing the short-term strengths and weaknesses and the long-term capabilities and strategies of both the key current and the key potential competitors; 3) interfunctional coordination is the coordinated 
utilization of company resources in for creating superior value for target customers. Market orientation from Narver and Slater is known as cultural approach.

On the other hand, Kohli and Jaworski (1990) split the practices related to market orientation into three components: (1) intelligence generation; (2) intelligence dissemination; and (3) responsiveness. Intelligence generation refers to the collection of relevant information from the environment, whereas intelligence dissemination pertains to its distribution and sharing across different departments within the firm. Finally, responsiveness reflects the use of this information to develop and implement strategies that have been adapted to the opportunities and threats in the external environment. Market orientation from Kohli\&Jaworski is known as behavioral approach.

\section{MARKET ORIENTATION FROM NARVER \& SLATER}

Customer orientation and competitor orientation include all of the activities involved in acquiring information about the buyers and competitors in the target market and disseminating it through the business. Interfunctional coordination, is based on the customer and competitior information and comprises the business's coordinatied efforts, typically involving more than the marketing department, to create superior value for the buyers. In sum, the three components of a market orientation comprehend the activities of market information acquisition and dissemination and the coordinated creation of customer value.

Customer orientation can be defined as an active firm-wide process, which drives a firm to continuously identify and meet their customer needs to gain sufficient knowledge to generate superior value to its customers (Kahn, 1991). A customer orientation emphasizes understanding target customers sufficiently to continuously create superior value for them (Narver and Slater, 1990). Because customers' needs change rapidly, a customer orientation requires a clear understanding of both the present and future demand dynamics of target customers. With its external focus on collecting, analyzing, and disseminating information about customers, a customer-oriented firm can anticipate its customers' changing needs and respond to them through continuous innovation (Zhou, Brown, \& Dev, 2009).

Customer orientation becomes more important in the case of a rapidly changing market environment. The organization becomes capable to sense the market changes on time and takes prompt actions to effectively respond to these changes (Zhou, Brown, \& Dev, 2009).

Competitor orientation can be understood as a firm-wide effort to understand the market or an industry where it is operating in and to continuously monitor the activities of its competitors, learn from their successes and failures to ensure that its own product will be a real improvement over those of its competitors (Kahn, 2001).

Competitor orientation essentially focuses on identifying (1) current and potential competitors, (2) the technologies they utilize, and (3) whether they represent an attractive alternative from the perspective of the target customers (Narver and Slater, 1990). Competitor oriented businesses watch competitors closely, match the marketing initiatives of competitors quickly, and attempt to understand both the short-term strengths and weaknesses and longterm capabilities and strategies of current and potential competitors. Then, using their rivals as a frame of reference, competitor-oriented firms can identify their own advantages and disadvantages.

Inter-functional coordination focuses on the dissemination and use of market information through coordinated efforts across the whole firm and emphasizes the collective use of the 
organization's resources to deliver superior customer value (Narver and Slater, 1990). Interfunctional coordination is the coordination of all departments and functional areas in the business in utilizing customer and other market information to create superior value for customers (Awwad \& Agti, 2011).

The basic idea is that every employee of a company can contribute something of value to customers, so if the firm can coordinate and integrate its financial, human, and other resources, it can provide goods and services that better suit its customers' needs. In addition, by improving cooperation among different departments, inter functional coordination can lead to greater efficiency and thereby decrease production and administration costs (Jaworski and Kohli, 1993).

Market orientation is a potential resource that can lead the organizations towards a competitive advantage in the market. However, this resource cannot be successfully utilized in its full capacity until the internal factors are taken into consideration by the organization. One of the important internal factors is the interaction between the employees from different departments of the organization performing different functions (Hunt \& Morgan, 1995). This interaction is crucial because the employees cannot learn the market orientation practices easily from the manuals and handbooks. The interaction between the employees from different functions initiates a learning process in the organization where one group of employees learn from the others (Bharadwaj, Waradarajan, \& Fahy, 1993).

Hence, market orientation should not only be focusing on developing a response mechanism to the challenges coming from the external environment; rather it should be complete system addressing the external and internal challenges simultaneously (Jaworski \& Kohli, 1990).

\section{EXTERNAL ENVIRONMENT FACTORS}

Organization as a system cannot be separated from its external environmental factors. One theory about external environmental factors was stated by Jaworski \& Kohli. According to Jaworski and Kohli (1993) there are three important components of external environmental factors as follows.

1. Market turbulence, refers to the level of instability in the external environment which forces firms to change their strategies in the face of changing customer needs (Golden, Doney, Johnson, Smith, 1985). In an environment characterized with a high level of market turbulence, products and production processes become obsolete very fast, forcing firms to change their product lines and processes. The introduction of new products is partly driven by innovations from other competitors and partly because of the demand from customers. A good understanding of competitors' actions and customers' preferences becomes very important for firms when the level of market turbulence is high. Market orientation helps firms develop the ability to adapt and respond to the challenges from competitors and the evolving needs of customers in a turbulent environment (Davis, Morris, Allen, 1991). On the contrary, in a stable environment, where customers' needs and preferences do not change frequently, firms do not have to be market oriented (Appiah-Adu, 1998).

2. Technological turbulence, refers to the rate of technological change. The importance of technological turbulence emanates from the fact that technology has emerged as a major source of competitive advantage in the past decade (Lengnick-Hall, 1992). Weerawardena and O'Class (2004) suggested that firms that actively engage in learning changing customer preferences and competitor behavior, and integrate such knowledge in the production process can outperform their counter parts, which do not care about technological developments. 
3. Competitive intensity, refers to extent of rivalry among different players in an industry. The level of competitive intensity determines a firm's choice of strategic actions and responses (Chen and Miller, 1994). When the level of competitive intensity is low, firms can perform well even if they are not highly market oriented (Kohli and Jaworski, 1990). This is because, in an environment of low competitive intensity, customers do not have much choice and they remain stuck with whatever is available in the market place. In contrast, under conditions of intense competition, customers have many options, and will reject the products and services that do not meet their expectations.

\section{MARKET ORIENTATION AS AN APPROACH FOR SMES IN DEALING WITH EXTERNAL ENVIRONMENT}

Small and medium enterprises (SME) demanded to develop market orientation concepts in their organizations in order to synchronize with the changing of business environment. Several previous studies indicated better performer in some companies when they focus on market orientation with particular emphasis on flexibility and speed of (Keskin, 2006). Basically market orientation is the first step to response on environment business changing. Becherer, Halstead, Haynes (2003) "noted that small firms that are market- oriented could enjoy a potential sustainable competitive advantage since they have simpler organization structures, more flexibility and adaptability, and a greater capacity for speed and innovation."

Likewise, market orientation in small businesses represents a continuous response to customer wants and needs. This response facilitates the development of strategies, focused upon the creation of customer value, to achieve competitive advantage (Pelham, 2000). However, the development of market orientation literature in relation to small businesses has taken into consideration the specific differences between small businesses and larger businesses. In small business literature a common theme is the issue of resource constraints relating to time, expertise, finance or labor, for example. Overcoming resource constraints, competitive advantage is leveraged from the speed with which they can respond to customers' wants and needs (Li, Zhao, Tan, Liu, 2008).

The most common process for understanding environments is through environmental scanning, which forms an inherent aspect of market orientation with its focus on gathering and analyzing information and trends taking place outside the business. When operating under conditions of environmental uncertainty, O'Dwyer, Gilmore, Carson (2009) state that small business owner-managers will make marketing decisions to adjust in an informal, nonsequential and unstructured fashion. Droege and Marvel (2009) found that small businesses perceiving high levels of environmental uncertainty tended to rely on emergent rather than deliberate strategies.

The nature of market orientation in small businesses is not therefore characterized by formalized and complex processes organized around the generation, dissemination of, and response to market information and intelligence (Kohli and Jaworski, 1990), as in larger firms. Small businesses prefer pragmatic action in the immediate time-frame depending on speed and agility to respond to customers, rather than planning and the contemplation of future desirables (Li, Zhao, Tan, Liu, 2008). The presence of a market orientation is therefore an important facilitator of flexible planning in small firms helping to improve their performance particularly under conditions of environmental uncertainty. This builds upon the capacity for adjustment, and the facility to change, which are characteristics of smaller businesses (AppiahAdu and Singh, 1998). 
Business organizations will always deal with with their external environment. The relationship between market orientation and the external environment has become a quite popular research topic among academics. The observation, reveals that most researchers use the concept of cultural market orientation from Narver and Slater. Following are some studies on market orientation using cultural approach and external environmental factors as variables:

Tabel 1

Research with Market Orientation and External Environmental Factors as Variables at the SME Level

\begin{tabular}{|c|l|l|l|c|}
\hline No & Researcher & \multicolumn{1}{|c|}{ Market orientation } & $\begin{array}{l}\text { External } \\
\text { Factor }\end{array}$ & $\begin{array}{l}\text { Ebject of } \\
\text { research }\end{array}$ \\
\hline 1 & $\begin{array}{l}\text { Didonet, Simmons, } \\
\text { Villavicencio } \\
(2012)\end{array}$ & $\begin{array}{l}\text { Customer orientation, } \\
\text { Competitor orientation } \\
\text { Competitive intensity }\end{array}$ & $\begin{array}{l}\text { Market turbulence } \\
\text { Technology turbulence }\end{array}$ & SME in Brazil \\
\hline 2 & Maroofy (2013) & $\begin{array}{l}\text { Customer orientation, } \\
\text { Competitor orientation } \\
\text { Competitive intensity }\end{array}$ & $\begin{array}{l}\text { Market turbulence } \\
\text { Technology turbulence } \\
\text { Competitive intensity }\end{array}$ & SME in Iran \\
\hline 3 & $\begin{array}{l}\text { Azis and Yassin } \\
(2010)\end{array}$ & $\begin{array}{l}\text { Customer orientation, } \\
\text { Competitor orientation } \\
\text { Competitive intensity }\end{array}$ & $\begin{array}{l}\text { Market turbulence } \\
\text { Technology turbulence } \\
\text { Competitive intensity }\end{array}$ & SME in Malaysia \\
\hline 4 & $\begin{array}{l}\text { Gaur, Vasudevan, } \\
\text { Gaur (2008) }\end{array}$ & $\begin{array}{l}\text { Customer orientation, } \\
\text { Competitor orientation } \\
\text { Competitive intensity }\end{array}$ & $\begin{array}{l}\text { Market turbulence } \\
\text { Technology turbulence }\end{array}$ & SME in India \\
\hline
\end{tabular}

Source: Journals

The results of the research in the table generally show a positive influence of market orientation on business performance which is moderated positively by external environmental factors.

\section{CONCLUSION}

From the previous discussion, it can be concluded that:

1. Market orientation researchers at the SME level tend to choose the market orientation version of Narver \& Slater and use the three components namely, customer orientation, competitor orientation, and inter-functional coordination.

2. SMEs will always deal with external environmental factors that can affect company performance.

3. Market orientation can be used by SMEs as an approach in dealing with external environmental factors that are full of uncertainty.

\section{References}

Appiah-Adu, 1998, Market orientation and performance: empirical tests in a transition economy. Journal of Strategic Marketing, Vol.6 No.1, 25-45.

Appiah-Adu, K., Singh, S., 1998, Market orientation and performance: An empirical study of British SMEs, Journal of Entrepreneurship, Vol. 7 No.1, 27-47.

Awwad, M. S., \& Agti, D. A. M. ,2011. The impact of internal marketing on commercial banks' market orientation. International Journal of Bank Marketing, Vol.29 No.4, 308-332.

Aziz, N.A., Yassin, N.M.,2010, How Will Market Orientation and External Environment Influence the Performance among SMEs in the Agro-Food Sector in Malaysia? International Business Research, Vol.3 No.3, 154-164.

Becherer, R.C., Halstead, D., Haynes, P.J., 2003, Marketing orientation in SMEs: Effects of the internet environment, New England Journal of Entrepreneurship, Vol. 6 No.1, 13-22.

Bharadwaj, S. G., Varadarajan, P. R., \& Fahy, J.,1993, Sustainable competitive advantage in service industries: a conceptual model and research propositions. The Journal of Marketing, 83-99. 
Chen, M., Miller, D.,1994, Competitive attack, retaliation and performance: an expectancy-valence framework, Strategic Management Journal, Vol. 15 No. 2, 85-102.

Davis, D., Morris, M., Allen, J., 1991, Perceived environmental turbulence and its effects on selected entrepreneurship and organizational characteristics in industrial firms, Journal of Academy of Marketing Science, Vol. 19, 43-91.

Didonet, S., Simmons, G., Villavicencio, G. D., 2010, The relationship between small business market orientation and environmental uncertainty, Marketing Intelligence \& Planning, Vol. 30 Iss 7, 757 - 779.

Droege, S. and Marvel, M., 2009, Perceived strategic uncertainty and strategy formation in emerging markets, Journal of Small Business Strategy, Vol. 20 No. 2,. 43-60.

Gaur, Sanjaya S.; Vasudevan,Hari; Gaur,Ajai S. (2011), “Market orientation and manufacturing performance of Indian SMEs", European Journal of Marketing, Vol. 45 No. 7/8, pp. 1172-1193.

Golden, P., Doney, P., Johnson, D. and Smith, J.,1985, The dynamics of a market orientation in transition economies: a study of Russian firms, Journal of International Marketing, Vol. 3, 29-49.

Hunt, S.D. and Morgan, R.M..1995. The comparative advantage theory of competition, Journal of Marketing, Vol. 59, $1-15$.

Jaworski, B.J., Kohli A.K., 1993, Market Orientation: Antecedents and Consequences, Journal of Marketing,Vol.57 No.3, 53-70.

Kahn, K.B.,2001, Market orientation, interdepartmental integration and product development performance, Journal of Product Innovation Management, Vol. 18 No. 5, 314-323.

Keskin, H., 2006, Market Orientation, Learning Orientation and Innovation Capability in SMEs:An Extended Model, European Journal of Innovation Management, Vol.9 No.4, 396-417.

Kohli, A.K., Jaworski, B.J., 1990, Market Orientation: The Construct, Research Proposition, and Managerial Implications, Journal of Marketing, Vol.54 No.2, 1-18.

Lengnick-Hall, C.A.,1992, Innovation and competitive advantage: what we know and what we need to learn, Journal of Management, Vol. 18 No. 2, 399-429.

Li, Y., Zhao, Y., Tan, J. and Liu, Y., 2008, Moderating effects of entrepreneurial orientation on market orientationperformance linkage: evidence from Chinese small firms, Journal of Small Business Management, Vol. 46 No. 1, 113-33.

Maroofy, F., 2013, The effects of environmental factors and Market orientation's indexes on manufacturing performance of Iranian SMEs, International Journal of Academic Research in Business and Social Sciences, Vol. 3, No. 9, 418-431

Narver, J.C., Slater,S.F., 1990, The Effect of Market Orientation on Businss Profitability, Journal of Marketing, Vol.54 No.4, 20-35.

O’Dwyer, M., Gilmore, A. and Carson, D., 2009, Innovative marketing in SMEs, European Journal of Marketing, Vol. 43 No $1,46-61$

Pelham, A.M., 2000, Market Orientation and Other Potential Influences on Performance in Small and MediumSized Manufacturing Firms, Journal of Small Business Management, Vol.38 No.1, 48-67.

Weerawardena, J., O'Cass, A., 2004, Exploring the characteristics of marketing-driven firms and antecedents of sustained competitive advantage, Industrial Marketing Management, Vol. 33 No. 5, 419-428.

Zhou, K. Z., Brown, J.R. \& Dev, C.S. (2009). Market orientation, competitive advantage, and performance: a demand-based perspective. Journal of Business Research, 62, 1063-1070. 